\title{
TELAAH KANDUNGAN ARSEN PADA SEDIMEN DI ESTUARI SUNGAI MARISA, KABUPATEN POHUWATO, GORONTALO
}

\section{(Analytical Study of the Arsenic content from Marisa River in Pohuwato District of Gorontalo)}

\author{
Rapik Kasan ${ }^{1 \star}$, Rizald Max Rompas ${ }^{1}$, Natalie D.C Rumampuk ${ }^{1}$
}

1. Program Studi IImu Kelautan, Fakultas Perikanan dan IImu Kelautan, Universitas Sam Ratulangi, Manado

*e-mail : rapikkasan@gmail.com

Arsenic (As) is a toxic chemical that can kill aquatic organism and humans, these chemicals can come from industrials or from inside of the earth. Indentification of As content in the sediment of Marisa River estuary was using spectrophotometer (ICP-OES/ Inductively Coupled Plasma optical emission spectrometry). The results of the research, the Arsenic content in sediments in a place close to Hele Village (point 1) was $4 \mathrm{mg} / \mathrm{kg}$; the river located in the village of Batu Pasang (point 2) was $3 \mathrm{mg} / \mathrm{kg}$; the sediment sample from the river near Buntulia village (near the beach) was detected only $2 \mathrm{mg} / \mathrm{kg}$. When this was juxtaposed with the International metals quality standard, Arsenic in the sediment of Marisa River was under the threshold.

Keywords: Arsenic, Toxic chemical, Marisa River

Arsen (As) adalah suatu kimia bersifat racun yang dapat mematikan organisme perairan dan manusia, kimia ini bisa berasal dari buangan industri ataupun dapat juga berasal dari perut bumi. Telah dilakukan penelitian kandungan As di sedimen estuari Sungai Marisa, Kabupaten Pohuwato, Gorontalo. Identifikasi kimia arsen menggunakan alat spektrofotometer (ICP-OES/ Inductively Coupled Plasma optical emission spectrometry). Hasil yang diperoleh, kandungan di sedimen sungai dekat Desa Hele (titik 1) adalah $4 \mathrm{mg} / \mathrm{kg}$; di sungai terletak di Desa Batu Pasang (titik 2) sebesar $3 \mathrm{mg} / \mathrm{kg}$; di sedimen sungai dekat Desa Buntulia (titik 3) adalah $3 \mathrm{mg} / \mathrm{kg}$, sedang dititik 4, muara sungai (dekat pantai) hanya terdeteksi $2 \mathrm{mg} / \mathrm{kg}$. apabila disandingkan dengan standar mutu logam di sedimen secara internasional, kandungan arsen disedimen Sungai Marisa masih dibawah ambang batas.

Kata kunci: Arsen, Kimia arsen, Sungai Marisa

\section{PENDAHULUAN}

Perkembangan dan kemajuan
teknologi dengan memanfaatkan
sumberdaya alam yang ada telah
memberikan peluang bagi peningkatan
kesejahteraan manusia. Berbagai upaya telah dilakukan untuk memenuhi kebutuhan manusia, sehingga tanpa disadari kegiatan yang dilakukan tersebut dapat memberi dampak yang buruk bagi lingkungan, yaitu terjadi degradasi lingkungan. $\mathrm{Hal}$ ini mengakibatkan semakin merosotnya sumberdaya hayati yang tersedia di alam, baik secara kualitas maupun kuantitas.
Indonesia mempunyai wilayah kelautan yang letaknya sangat strategis terletak diantara dua benua (Asia dan Australia) dan dua samudra (Hindia dan Pasifik). Memiliki potensi sumberdaya laut yang besar antara lain sumber daya perikanan, terumbu karang, mangrove, mineral di dasar laut, dan minyak bumi. Wilayah tersebut telah banyak aktifitas perekonomian yang dilakukan di antaranya kegiatan perikanan (tangkap dan budidaya), industri, pelabuhan dan pariwisata dan pemanfaatannya telah memberikan sumbangan yang berarti, baik bagi peningkatan taraf hidup masyarakat maupun sebagai penghasil devisa negara (Hayati, 2009). Rompas dkk. 
(2009) menyatakan bahwa hasil dari aktivitas manusia sebagai tanda adanya kemajuan teknologi dalam bidang industri, mineral di dasar laut, transportasi laut dan sebagainya, sehingga dapat mengakibatkan munculnya beraneka ragam zat yang berbahaya bagi lingkungan hidup dan pada akhirnya dapat merusak lingkungan termasuk organisme yang hidup di dalamnya.

Berdasarkan Undang-Undang No. 32 tahun 2009 pengertian Pencemaran lingkungan hidup adalah masuk atau dimasukkanya makhluk hidup,zat, energi, dan/atau komponen lain ke dalam lingkungan hidup oleh kegiatan manusia sehingga melampaui baku mutu lingkungan hidup yang telah ditetapkan.

Hakekatnya polutan di perairan, berupa limbah rumah tangga, pestisida, minyak bumi, logam berat ataupun bahan kimia lainnya. Halmana itu polutan dapat menyebabkan tekanan pada populasi biota di perairan, mempengaruhi metabolisme dan reproduksi, perubahan tingkah laku dan dapat menyebabkan penurunan kualitas lingkungan dengan cepat sehingga tidak dapat berfungsi sebagaimana mestinya (Darmono, 2001). Menurut Rompas dan Rumampuk (2014) mengatakan bahwa umumnya mineral dan polutan yang berada di perairan laut berasal dari daratan melalui sungai.

Wilayah Provinsi Gorontalo terdapat beberapa lokasi kegiatan pertambangan emas tradisional yang dilakukan oleh masyarakat. Salah satunya berada di Kabupaten Pohuwato, Kecamatan Marisa tepatnya lokasi kegiatan berada di Gunung Pani. Mineralisasi emas primer di daerah Gunung Pani, terjadi pada batuan lava riodasit, breksi dan batuan piroklastik lainnya, tipe cebakan berupa porfiri $\mathrm{Au}$ yang menempati daerah perbukitan di sekitar Gunung Pani. Bijih emas primer selain mengandung perak, juga logam $\mathrm{Cu}, \mathrm{Pb}, \mathrm{Zn}, \mathrm{Cd}$, As dan Hg. Cebakan emas sekunder dijumpai pada residual soil, dan sebagai endapan emas aluvial yang menempati lembah Sungai di sekitar Gunung Pani yang mengalir terus sampai ke Sungai Marisa (Suhandi, 2005). Kekhawatiran bahan kimia arsen (As) dapat masuk ke perairan laut seputar teluk tomini, yang pada akhirnya akan masuk ke rantai makanan di laut.

\section{METODE PENELITIAN}

Pengambilan sampel dilakukan di estuari Sungai Marisa. Sungai Marisa tersebut dipilih karena Sungai Marisa diketahui merupakan tempat pembuangan limbah yang salah satunya dihasilkan oleh pertambangan emas dan juga limbah yang dihasilkan dari kegiatan pertanian seperti pestisida yang dibuang ke Sungai Marisa padahal Sungai Marisa banyak digunakan untuk berbagai aktifitas salah satunya untuk mengaliri persawahan. Untuk mengantisipasi akumulasi logam berat arsen (As) di lingkungan perairan maka dilakukan penelitian tentang kandungan arsen di sedimen di estuary Sungai Marisa.

Pengujian analisis arsen pada sedimen dilakukan di Water laboratory Nusantara (WLN) dengan menggunakan metode Inductively Coupled Plasma optical emission spectrometry (ICP-OES) instrument. Secara garis besar pengujian kandungan Arsen dilakukan dalam dua bagian yaitu :

\section{Penetapan Kadar Air}

Penetapan kadar air dilakukan dengan cara memanaskan sedimen dalam oven dengan suhu $105^{\circ} \mathrm{C} \pm 5^{\circ} \mathrm{C}$ selama 24 jam, kemudian didinginkan dalam desikator, lalu ditimbang.

\section{Digest}

Ditambahkan $5 \mathrm{ml} \mathrm{HNO}_{3}$ pekat, kemudian diikuti dengan penambahan $5 \mathrm{ml} \mathrm{HCL}$ pekat ke dalam 5 gram sampel sedimen. Lalu dibiarkan selama satu jam lalu dipanaskan pada suhu $85^{\circ} \mathrm{C}-90^{\circ} \mathrm{C}$ selama 2 jam. Kemudian didinginkan. Selanjutnya sampel 
ditambahkan $50 \mathrm{ml}$ air ultrapure dan terakhir di centrifuge dengan kecepatan 2000-3000 rpm selama 10 menit. Sampel siap dianalisis dengan menggunakan Inductively Couple Plasma Optical emission spectrometry (ICP-OES) instrument.

\section{HASIL DAN PEMBAHASAN}

Studi ini telah dilakukan di bagian estuari DAS Marisa, Kabupaten Pohuwato. Sedimen yang berada di Sungai Marisa umumnya berukuran kecil. Kabupaten Pohuwato terletak pada 00.22'-00.57' Lintang Utara dan 1210.23'-1220.19' Bujur Timur. Luas Kabupaten Pohuwato secara keseluruhan mencapai $4.244,31 \mathrm{~km}^{2}$, sekitar $36,77 \%$ dari luasan total Provinsi Gorontalo. Adapun batas wilayah Kabupaten Pohuwato adalah sebagai berikut: sebelah utara berbatasan dengan Kabupaten Buol (Provinsi Sulawesi Tengah) dan Kabupaten Gorontalo Utara, sebelah timur berbatasan dengan Kabupaten Boalemo, sebelah selatan berbatasan dengan Teluk Tomini, dan sebelah barat berbatasan dengan Kabupaten Buol dan Kabupaten Parigi Moutong (Provinsi Sulawesi Tengah).

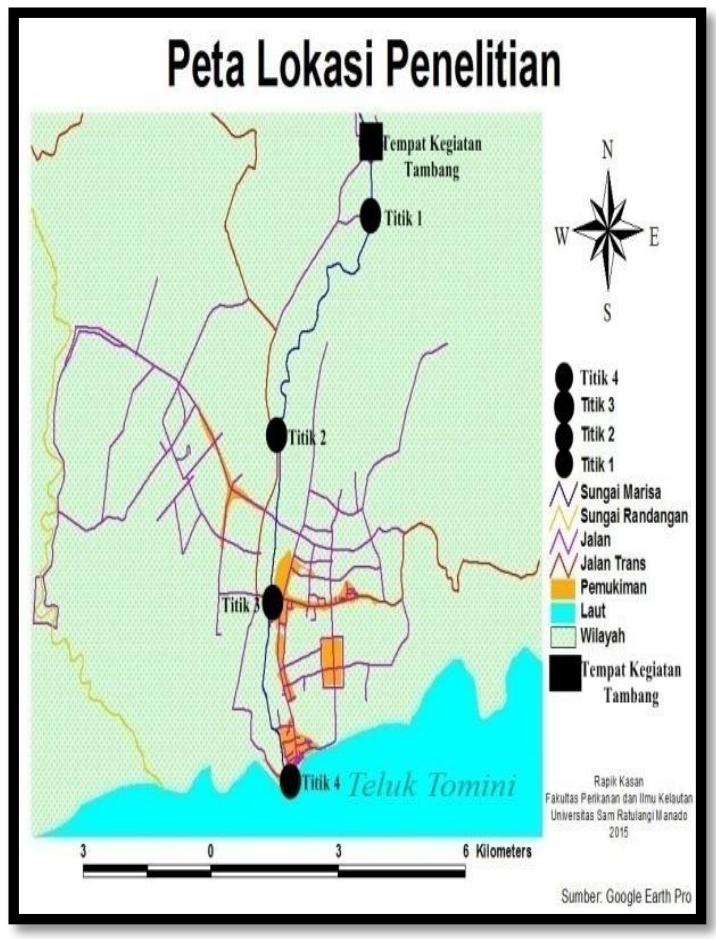

Gambar 1. Lokasi pengambilan

Dari keempat tempat pengambilan sampel didapatkan kandungan arsen pada sampel sedimen adalah di Desa Hele (titik 1 ) yaitu sebesar $4 \mathrm{mg} / \mathrm{kg}$ berat kering selanjutnya di Desa Batu pasang (titik 2 ) yaitu sebesar $3 \mathrm{mg} / \mathrm{kg}$ berat kering kemudian di Desa Buntulia (titik 3 ) yaitu sebesar $3 \mathrm{mg} / \mathrm{kg}$ dan di Desa Bulili (titik 4) mempunyai konsentrasi sebesar $2 \mathrm{mg} / \mathrm{kg}$.

Tingginya konsentrasi arsen di titik pertama karena titik pertama sangat dekat dengan pegunungan api, dan kecilnya konsentrasi arsen di titik terakhir yakni di muara Sungai karena adanya aksi laut seperti gelombang sehingga sedimen yang berada di muara Sungai Marisa tertransport ke bagian laut yang lain sehingga konsentrasi arsen yang diperoleh di muara Sungai begitu rendah dari titik pertama. Asumsi lain yakni Sungai Marisa digunakan juga sebagai penambangan pasir jadi pasir yang mengandung arsen sudah terangkut oleh penambang pasir. Melihat hasil konsentrasi arsen yang diperoleh di muara Sungai Marisa sangat rendah 
hal ini sangat baik bagi perairan laut yang merupakan Teluk Tomini karena hampir dapat dipastikan bahwa perairan laut yang ada di Kecamatan Marisa belum terkontaminasi logam berat arsen.

Jika dibandingkan dengan penelitian yang dilakukan oleh Suhandi pada tahun 2005 yang juga meneliti arsen maka konsentrasi arsen di Sungai Marisa mengalami penurunan, hal ini diakibatkan oleh berkurangnya aktifitas pertambangan yang dilakukan di Gunung Pani.

Konsentrasi arsen di Desa

Hele, Desa Batu pasang, Desa Buntulia, dan Desa Bulili diduga berasal dari pelapukan batuan alami karena di sekitar tempat pengambilan sampel tidak ditemukan adanya konsentrasi arsen (As) yang tinggi.

Hasil tersebut menunjukkan bahwa konsentrasi alami arsen dalam sedimen sungai berkisar antara 1-50 $\mathrm{mg} / \mathrm{kg}$. Konsentrasi arsen yang ada di sedimen dua kali lebih tinggi dibandingkan konsentrasi arsen di tanah. Hal ini disebabkan karena pelapukan batu yang lebih tinggi dan masukan dari sumber-sumber antropogenik sehingga kandungan arsen lebih tinggi di sedimen Sungai dari pada di tanah (Patel dkk. 2005).

Arsen yang didapat di Desa Hele, Desa Batu Pasang, Desa Buntulia dan Desa Bulili atau di muara Sungai Marisa diperkirakan masih dalam kontaminasi alami karena secara alami kandungan arsen dalam sedimen biasanya di bawah $10 \mathrm{mg} / \mathrm{kg}$ berat kering (Sukar, 2003). NRC (2001) dalam maksuk (2009) menambahkan bahwa semua batuan mengandung arsen 1-5 ppm, konsentrasi lebih tinggi ditemukan pada batuan beku dan sedimen, tanah hasil pelapukan batuan biasanya mengandung arsen (As) sebesar 0,1-40 ppm dengan rata-rata 5-6 ppm.

Kontaminasi arsen merupakan hasil dari proses alami geologi dan juga merupakan buangan dari manusia yang merupakan hasil dari kegiatan pertambangan, peternakan, industri dan pertanian (Patel $d k k$. 2005).

Kandungan arsen (As) dalam

sedimen dimasing-masing titik pengamatan lebih jelas disajikan pada Gambar 2 serta baku mutu arsen di sedimen.

Berdasarkan standar baku IADC/CEDA (1997) dalam Pasaribu, (2012) kadar normal arsen dalam sedimen di Sungai Marisa tidak terkontaminasi atau belum dikatakan tercemar karena berkisar dibawah 29 ppm yang merupakan level target. Jika mengacu kepada hal ini, maka kandungan arsen dalam sedimen di perairan ini masih dibawah level target namun sudah terdeteksi kandungan arsen. Walaupun konsentrasi ini mungkin masih rendah, namun bila terus menerus adanya suplai dari alam maupun dari kegiatan manusia maka akan terakumulasi dan akan berbahaya bagi organisme yang berada dalam perairan. Rochyatun dkk. (2004) menambahkan bahwa biota-biota yang hidup di lokasi yang mengandung logam akan terakumulasi dengan logam tersebut.

\section{Parameter penunjang}

Parameter kimia dan fisika yang turut mempengaruhi kandungan logam berat dalam perairan adalah suhu, derajat keasaman $(\mathrm{pH})$ dan kecepatan arus. Untuk pengukuran parameter penunjang seperti suhu, derajat keasaman $(\mathrm{pH})$ dan kecepatan arus dilaksanakan secara in situ (dilakukan langsung di lokasi penelitian). Hasil pengukuran parameter penunjang di Sungai Marisa dapat dilihat pada Tabel 1. Secara umum tidak ada parameter yang ekstrim dan masih dapat mendukung kehidupan organisme perairan.

Organisme perairan mempunyai batas toleransi yang berbeda terhadap perubahan suhu perairan bagi kehidupan dan pertumbuhan organisme perairan. Oleh karena itu suhu merupakan salah satu faktor fisika perairan yang sangat penting bagi 
kehidupan organisme atau biota perairan. Suhu permukaan pada dasarnya tergantung dari intensitas cahaya yang masuk ke lingkungan perairan, sehingga tinggi rendahnya suhu di perairan tergantung penetrasi sinar matahari yang masuk ke perairan tersebut (Nontji, 1984 dalam Nasprianto, 2010).

Tabel 1. Parameter penunjang

\begin{tabular}{|l|l|l|l|l|}
\hline \multirow{2}{*}{ Parameter } & \multicolumn{4}{|c|}{ Sungai Marisa } \\
\cline { 2 - 5 } & $\begin{array}{l}\text { Titik } \\
\text { I }\end{array}$ & $\begin{array}{l}\text { Titik } \\
\text { II }\end{array}$ & $\begin{array}{l}\text { Titik } \\
\text { III }\end{array}$ & $\begin{array}{l}\text { Titik } \\
\text { IV }\end{array}$ \\
\hline Suhu $\left(^{\circ} \mathrm{C}\right)$ & 29 & 29 & 29 & 30 \\
\hline $\mathrm{pH}$ & 7 & 7 & 8 & 7 \\
\hline $\begin{array}{l}\text { Kec.Arus } \\
\text { (m/det) }\end{array}$ & 1,5 & 1,2 & 1,3 & 1,7 \\
\hline
\end{tabular}

Hasil pengukuran suhu pada
tiap titik pengambilan contoh menunjukkan bahwa suhu di Sungai Marisa berkisar antara $29-30^{\circ} \mathrm{C}$. Suhu terendah terdapat pada bagian hulu Sungai Marisa dan tertinggi pada muara Sungai Marisa. Tingginya suhu yang diperoleh di Sungai Marisa ini berhubungan dengan letak geografis dari Kabupaten Pohuwato yang hampir berada pada daerah khatulistiwa, sehingga intensitas penyinaran matahari sangat tinggi dan juga bertepatan dengan musim panas yang melanda Kapubapen Pohuwato. Tingginya intensitas penyinaran matahari, menyebabkan tingginya tingkat penyerapan panas ke dalam perairan. Kondisi kisaran suhu perairan Sungai Marisa masih dalam batas nilai toleransi bagi kehidupan organisme perairan pada umumnya. Nybakken (1988) dalam Erlangga (2007) menambahkan bahwa kisaran suhu yang baik bagi kehidupan organisme perairan adalah antara $18-30^{\circ} \mathrm{C}$. Hutagalung (1984) menambahkan bahwa kenaikan suhu tidak hanya meningkatkan metabolisme biota di perairan. Tetapi juga dapat juga meningkatkan toksisitas logam berat di perairan.

$\mathrm{pH}$ sangat penting sebagai parameter kualitas air karena $\mathrm{pH}$ berperan buffer atau penyangga di perairan. Selain itu, ikan dan makhluk lainnya hidup pada selang $\mathrm{pH}$ tertentu. Apabila derajat keasaman sangat rendah atau tinggi dapat membuat biota menjadi stres. Dengan diketahuinya nilai $\mathrm{pH}$, kita dapat mengetahui apakah air tersebut sesuai atau tidak untuk menunjang kehidupan mereka (Odum, 1971 dalam Erlangga, 2007).

Berdasarkan hasil pengukuran derajat keasaman $(\mathrm{pH})$ dari empat titik sampling di sekitar Sungai Marisa di mana untuk titik pertama diperoleh nilai $\mathrm{pH} 7$, titik kedua nilai $\mathrm{pH} 7$, titik ketiga nilai $\mathrm{pH} 8$ dan titik keempat nilai $\mathrm{pH} 7$. Nilai $\mathrm{pH}$ perairan berkaitan dengan sifat kelaruan logam berat, pada $\mathrm{pH}$ yang rendah, ion logam berat akan dilepaskan ke dalam kolom air. Selain itu $\mathrm{pH}$ juga dapat mempengaruhi toksisitas senyawa kimia seperti amonia, sianida dan logam berat. Semakin rendah nilai $\mathrm{pH}$ maka toksisitas logam berat akan semakin meningkat, sebaliknya semakin tinggi nilai $\mathrm{pH}$ maka logam berat akan mengalami pengendapan (beveridge, 1987 dalam Pasaribu 2012). Jika dihubungkan dengan hasil $\mathrm{pH}$ yang diperoleh di Sungai Marisa maka arsen tidak akan terlepas karena $\mathrm{pH}$ di Sungai Marisa bersifat netral.

Hasil pengukuran kecepatan arus yang dilakukan di Sungai Marisa di titik pertama dengan kecepatan arus 1,5 $\mathrm{m} / \mathrm{det}$, selanjutnya di titik kedua dengan kecepatan arus 1,2 $\mathrm{m} / \mathrm{det}$, kemudian di titik ketiga dengan kecepatan arus 1,3 m/det dan di titik keempat 1,7 $\mathrm{m} /$ det. Selanjutnya Hutagalung dan Evans (1985) menyatakan bahwa kecepatan arus permukaan sangat dinamis dan umumnya dipengaruhi kecepatan angin. Kecepatan arus digunakan untuk memprediksi kapan logam berat akan sampai pada suatu tempat dan kecepatan arus juga dapat 
berpengaruh pada distribusi logam berat di perairan.

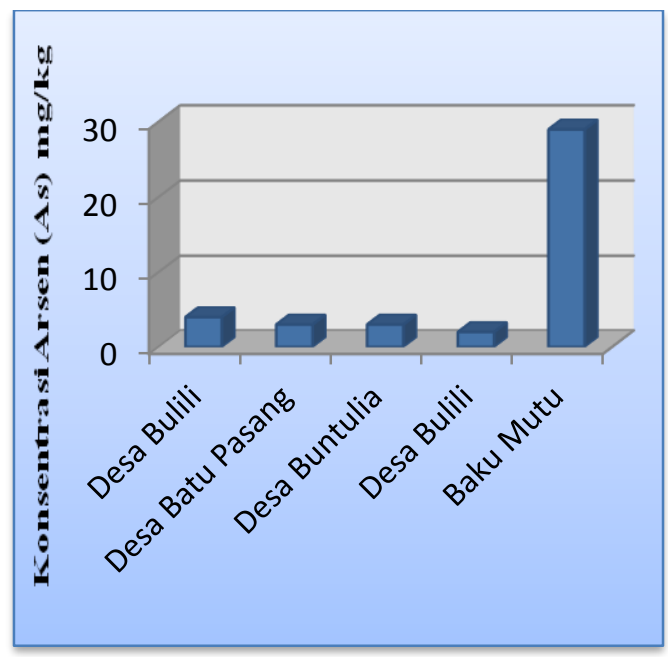

Gambar 2. Konsentrasi arsen (As) di sedimen dan Standar Baku Mutu Menurut IADC/CEDA (1997) dalam Pasaribu, (2012).

\section{KESIMPULAN}

Kandungan arsen (As) dalam sedimen di Sungai Marisa di Desa Hele (titik 1) adalah $4 \mathrm{mg} / \mathrm{kg}$ selanjutnya di Desa Batu Pasang (titik 2) adalah 3 $\mathrm{mg} / \mathrm{kg}$ kemudian di Desa Buntulia (titik 3) adalah $3 \mathrm{mg} / \mathrm{kg}$ dan di Desa Bulili (titik 4) adalah $2 \mathrm{mg} / \mathrm{kg}$. Kandungan arsen (As) yang terkandung di sedimen di Sungai Marisa masih di bawah Standar Baku Mutu Menurut Dutch Quality Standars for Metal in Sediment IADC/CEDA (1997) dalam Pasaribu, (2012). Parameter kimia dan fisika yang turut mempengaruhi kandungan logam berat dalam perairan seperti suhu, derajat keasaman $(\mathrm{pH})$ dan kecepatan arus. Hasil pengukuran suhu berkisar 29-30 $0^{\circ} \mathrm{pH}$ berkisar 7-8 dan kecepatan arus berkisar 1,2-1,7. Dari hasil yang didapat bahwa Sungai Marisa masih dapat menunjang kehidupan biota yang hidup didalamnya.

\section{DAFTAR PUSTAKA}

Darmono. 2001. Lingkungan Hidup dan Pencemarannya, Hubungannya dengan Toksikologi Senyawa Logam. Jakarta : UI Press.

Erlangga. 2007. Efek Pencemaran Perairan Sungai Kampar Di Provinsi Riau Terhadap Ikan Baung (Hemibagrus Nemurus). Tesis Sekolah Pascasarjana IPB Bandung.

Hayati, N. 2009. Analisis Kadar Arsen (As) Pada Kerang (Bivalvia) Yang Berasal Dari Laut Belawan. Skripsi S1 Fakultas Kesehatan Masyarakat, Universitas Sumatera Utara.

Hutagalung, H.P. 1984. Logam berat dalam lingkungan laut. Jurnal Oseana, Volume IX(1) 11-20.

Hutagalung, S., Evans, S.M. 1985. Pengantar Oseanografi. UI. Press. Jakarta.

Maksuk. 2009. Kadar Arsenik dalam Air Sungai, Sedimen, Air Sumur dan Urin Pada Komunitas di Daerah Sungai Musi Provinsi Sulawesi Selatan. Politeknik Kesehatan.

Nasprianto, 2010. Analisis Kandungan Timbal (Pb) pada Air dan Sedimen di Sekitar Perairan Kema dan Perairan Likupang Timur Kabupaten Minahasa Utara. Skripsi Fakultas Perikanan dan IImu Kelautan Program Studi IImu Kelautan Universitas Sam Ratulangi.

Pasaribu, D.J. 2012. Studi Pelepasan Arsen (As) dari Sedimen di Teluk Jakarta dan Bioakumulasi Arsen dalam Bentuk Senyawa Tunggal dan Campuran pada Cyprinus carpio. Skripsi Fakultas Matematika dan IImu Pengetahuan Alam Departemen Kimia Depok Universitas Indonesia. 
Patel, K., Shrivas, K.S., Brandt, R., Jakubowski, N., Corns, W., Hoffmann, P. 2005 Arsenic Contamination in Water, Soil, Sediment and Rice of Central India. Environmental Geochemistry and Health., 27, 131-145.

Undang-undang Republik Indonesia Nomor 23 Tahun 1997 tentang Perlindungan dan Pengelolaan Lingkungan Hidup, Jakarta.

Rochyatun., Lestari., Rozak. 2004. Kondisi Perairan Muara Sungai Digul dan Perairan Laut Arafura Dilihat dari Kandungan Logam Berat. Oseanologi dan Limnologi di Indonesia No. 36:15-31 ISSN 0125 - 9830.

Rompas, R.M., Rumampuk, N.D.C., Rompas, R.J. 2009. Oseanografi Kimia. Penerbit Sekretariat Dewan Kelautan Indonesia.

Rompas, R.M., Rumampuk, N.D.C. 2014. Geokimia Laut. UNSRAT PRESS.

Suhandi, S.J.S. 2005. Pendataan Sebaran Unsur Merkuri Pada Wilayah Pertambangan Gunung Pani Dan Sekitarnya Kabupaten Pohuwato, Provinsi Gorontalo. Hasil Kegiatan Subdit Konservasi 